\title{
MODELAMENTO DA CLASSIFICAÇÃO DE PELOTAS VERDES DE MINÉRIO DE FERRO EM PENEIRAS DE ROLOS PELO MÉTODO DOS ELEMENTOS DISCRETOS *
}

\author{
Benito Barbabela e Silva ${ }^{1}$ \\ Rodrigo Magalhães de Carvalho ${ }^{2}$ \\ Emerson Reikdal da Cunha ${ }^{3}$ \\ Pedro Porto Cavalcantit \\ Luís Marcelo Marques Tavares 5
}

\begin{abstract}
Resumo
O pelotamento é a mais complexa etapa de aglomeração de finos de minério de ferro. Sua resposta é naturalmente oscilante, sendo bastante influenciada pelas características físicas obtidas nos processos de beneficiamento mineral que a precedem e tem papel crucial para a etapa de tratamento térmico de sinterização à jusante. O presente trabalho aborda 0 processo de classificação de pelotas verdes, sólidos singulares de aspecto deformável e pegajoso, em peneiras de rolos por modelamento por aplicação de Método dos Elementos Discretos. Esta técnica mostra-se como uma importante ferramenta pois supera as limitações impostas na modelagem física (quantificação e identificação de fluxos por ausência de instrumentação em escala industrial, amostragem sem representatividade) ao reproduzir de forma verossímil as repostas do sistema para importantes variáveis de controle: comprimento de gap, umidade, dispersão de tamanhos e resistência das pelotas.
\end{abstract}

Palavras-chave: Pelotas verdes; Método de Elementos Discretos; Pelotamento; Peneira de rolos.

\section{MODELING OF CLASSIFICATION OF IRON ORE GREEN PELLETS ON ROLLER SCREENS USING THE DISCRETE ELEMENT METHOD}

\begin{abstract}
Balling is the most complex stage in agglomeration of iron ore fines. Its response is naturally oscillating and it is strongly influenced by the physical characteristics obtained in the preceding mineral processing stages and, at the same time, playing a crucial role in the heat treatment step of sintering downstream. The present work deals with the classification process of green pellets, single solids with a deformable and sticky aspect, on roller screens by modeling using the Discrete Element Method. This technique has revealed to be an important tool because it overcomes the limitations imposed in the physical modeling (quantification and identification of flows due to the absence of instrumentation on industrial scale, no representative sampling) by reproducing in a credible way the system's responses to important control variables: length of gap, moisture, size distribution and mechanical strength of the pellets.
\end{abstract}

Keywords: Green pellets; The Discrete Element Method; Balling; Roller screens.

1 Engenheiro Metalurgista, Engenheiro de Processos, Unidade Técnica Minas Gerais/Departamento de Pelotização, VALE SA, Nova Lima, Minas Gerais, Brasil.

2 Engenheiro Químico, M.Sc.., D.Sc., Professor Adjunto, Programa de Engenharia Metalúrgica e de Materiais, COPPE/UFRJ, Rio de Janeiro, RJ.

3 Engenheiro Químico, M.Sc., D.Sc., Pesquisador Pós Doutor, Programa de Engenharia Metalúrgica e de Materiais, COPPE/UFRJ, Rio de Janeiro, RJ.

4 Engenheiro Metalurgista, M.Sc., doutorando, Programa de Engenharia Metalúrgica e de Materiais, COPPE/UFRJ, Rio de Janeiro, RJ

5 Engenheiro de Minas, M.Sc., Ph.D, Professor Titular, Programa de Engenharia Metalúrgica e de Materiais, COPPE/UFRJ, Rio de Janeiro, RJ 


\section{INTRODUCTION}

Numerical simulation of granular materials is an important tool both for advancing the fundamental understanding of many natural phenomena in material science and geophysics, and for the design, control and optimization of systems for processing, manufacturing, storage and transportation of granular materials, e.g., grains, corn, pharmaceuticals pills, pellets, soil and minerals. In the mineral processing industry, experiments and in situ measurements are many times prohibitive for practical and economic reasons, and in these cases, mathematical modeling and simulation play an essential role in reaching a deeper understanding of the process, making radical improvements and the search of completely innovative solutions possible ${ }^{1}$. It is recognized and suggested that advances on balling process will forcefully pass through numerical simulations ${ }^{2}$.

In order to have a holistic view and a better understanding on pellets classification, a proper assessment of the performance of separation of pellets in roller screens is necessary. Such screen is very particular, being almost exclusively employed throughout industry in classification of green pellets. The control parameters of these screens are the diameters of the rolls, the number of rolls, their speed, the screen angle and the feed rate. The understanding of their effect is still very limited by both users and manufacturers, mainly due to:

i. Difficulties to analyze an inherently unstable process. Although optical measurement systems have presented good results in recent years by supplying information to advanced process controls, such analysis by scanning is done only to objects placed on the top of the bed. They also have limitations $^{3}$ of resolution that hardly identify objects smaller than approximately $8 \mathrm{~mm}$ and are totally unable to distinguish pellets smaller than $5 \mathrm{~mm}$.

ii. Circuits used for transporting pellets are very compact in order to reduce green pellets drops heights and distances in handling. As a result, belts used in each balling line do not have the necessary length to allow installing dynamic scales for continuously weighing the charge; even when room is available, CAPEx costs required to install such dynamic scales are significant and seldom have short or intermediate payback times;

iii. Pelletizing units usually have more than five production lines, equipped with drums, discs or both, which share conveyor belts to transport the green pellets. As such, the impact of small changes on any control variable in a production line is difficult and complex to evaluate and determine the extent of its influence, unless a huge effort is made and the given variable is changed in all lines at same time. This procedure is usually inefficient because many noisy variables can misguide conclusions.

iv. Pellet feed physical properties have a significant effect on balling yield and quality of green pellets. Its gradual impoverishment and mineralogical changes are more often challenges which many plants have been facing nowadays. As such, it is imperative that new arrangements of the process, which may not be of common usage in the past, be tested;

v. Green pellets sampling, handling and sieving in the laboratory are difficult, given their low strength, their amenability to easily lose weight and to have their shape altered if improperly handled;

vi. Simulation tools such as the discrete element method (DEM) have been increasingly used to analyze particle motion ${ }^{4,5}$, collision energies and 
amenability to produce wear in machines ${ }^{6}$, mainly in mineral processing ${ }^{7}$. Limited research and application has been dedicated to understand balling granulation $^{1,8,9}$

Therefore, any physical modeling of balling is quite challenging. In order to reach optimal balling yield (e.g. controlled return rates) and permeability of indurating furnace, a proper mathematical model becomes necessary.

To achieve this objective, the present work carries out exploratory simulations of pellet classification on roller screens at the discharges of discs at a pelletizing plant using the Discrete Element Method (DEM). From the results of these simulations the effects of undersize gap lengths, moisture content, size dispersion and resistance strength of green pellets (both qualitatively and quantitatively) are analyzed.

\section{MATERIALS AND METHOD}

Based on industrial information collected in a pelleting plant, such as mean discs feed rate, conveyor belts speed and width, number of rolls and gaps distribution, simulations (Figure 1) were performed on EDEM ${ }^{\circledR}$ from DEM Solutions and licensed to Laboratório de Tecnologia Mineral of COPPE/UFRJ, using the JKR contact model. Details of the model parameters and simulation setup can be found elsewhere ${ }^{10}$.

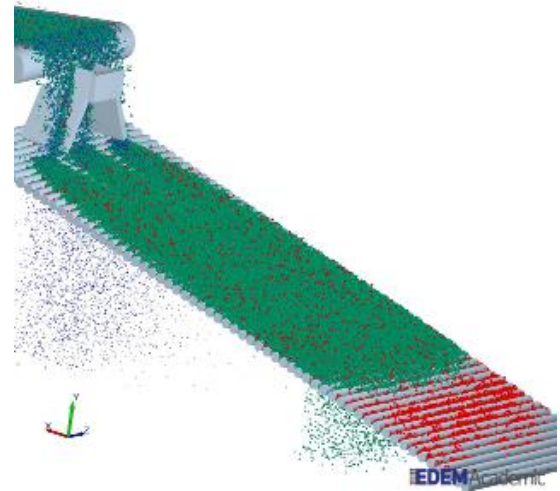

Figure 1. Simulation of green pellets classification in the roller screen.

A definition of relevant terms that will be used in the study is relevant, since they will be used in the analysis of the roller screens operation:

- Product: pellets contained in the size range of interest, namely from 8.0 to $18.0 \mathrm{~mm}$;

- Fines: pellets smaller than $8.0 \mathrm{~mm}$ in size;

- Coarse: pellets larger than $18.0 \mathrm{~mm}$ in size;

- Undersize: mass flow of material screened at roller screens' first 3/4 length (green rolls in Figure 1);

- On-size: mass flow of material screened at roller screens' last 1/4 length (yellow and blue in Figure 1);

- Oversize: mass flow of material not screened through gaps, passing over all rolls and discharged after the last roll;

- Fines removal efficiency: ratio of fines removed as undersize and fines fed, i.e., the complement of the screen by-pass;

- Product screening efficiency: Ratio of pellets ranging from 8 to $18 \mathrm{~mm}$ screened as on-size and the same range of pellets fed; 
- Loss of production: amount of product pellets screened as undersize or oversize.

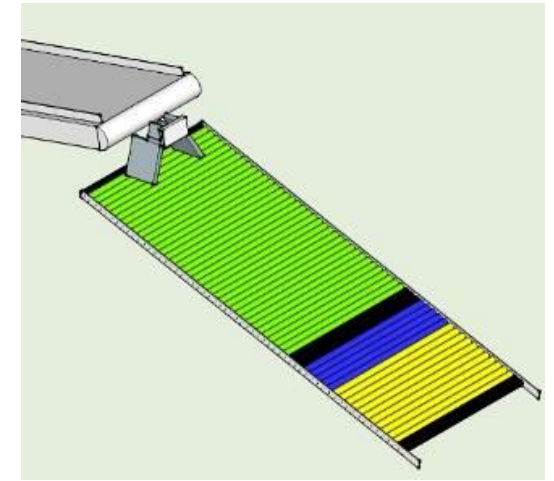

Figure 2. Schematic drawing of roller screen classifying areas in EDEM ${ }^{\boxplus}$ creator platform.

\section{RESULTS AND DISCUSSION}

From the analysis of the flow rates of the three roller screens output, it was observed that the system required a total time of $40 \mathrm{~s}$ in order to reach steady-state conditions from the beginning of the simulations, when no particles were in the screen. This result can be seen in Figure 3: at the beginning only feed is recorded at the conveyor transfer; after $5 \mathrm{~s}$, undersize pellets start to be removed, stabilizing after $20 \mathrm{~s}$ at around $10 \mathrm{t} / \mathrm{h}$. From this moment on, both on size and oversize flows are almost concomitantly registered, reaching relatively constant values after approximately $25 \mathrm{~s}$ of simulation. As such, the interval of time used for estimating the performance indices of the roller screen corresponded to between 40 and $60 \mathrm{~s}$, when all mass flows reached steady-state.

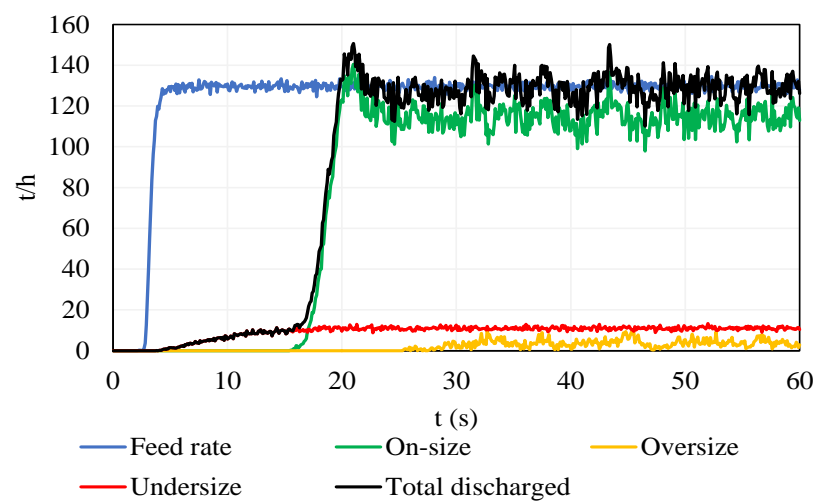

Figure 3. Evolution of mass flow registered in simulations for rollers screens screening process.

\subsection{Moisture content (interaction amongst solids contacts)}

One of the most common uncontrolled problems in a pelletizing plant is the raise of feed moisture content in balling. It can happen for many reasons: increase in specific surface area due to the change in the iron ore mineralogy, change in $\mathrm{pH}$ of the slurry that can make filtration very challenging, vacuum inefficiency in filtration or even occurrences of rain when the intermediate pile (reground, filtered and pressed stock) is reclaimed. In those operational situations, the screening process is directly affected. The cohesion among pellets and between them and fines increase 
substantially and they are carried as sticky/glued compact mass over the rolls. Fines removal efficiency (FRE) considerably drops and on-size contamination is very considerable and harmful to pellets bed permeability in pallets cars.

In order to mimic these cases, the energy of surface of JKR contact model was arbitrarily increased from 1.5 to $2.7 \mathrm{~J} / \mathrm{m}^{2}$ to simulate an increase in moisture content. Results shown in Figure 4 and Table 1 are in agreement to observations of real situations afore described. Cohesion among pellets increased to a certain level hauling masses fluxes downstream. Fines by-pass raised approximately $580 \%$ and fines screening efficiency sharply dropped from $92 \%$ to $54 \%$. Burnt pellets specification consider as product the fraction of pellets ranging from 8 to $18 \mathrm{~mm}$. From such point of view, the loss of production to oversize suffered little impact. Nevertheless, some balling analysts look closely at the range of pellets with sizes from 8 to $16 \mathrm{~mm}$. In this case, the loss of production is more than seven times larger. This is the worst bed condition of operation to green pellets induration sintering process.

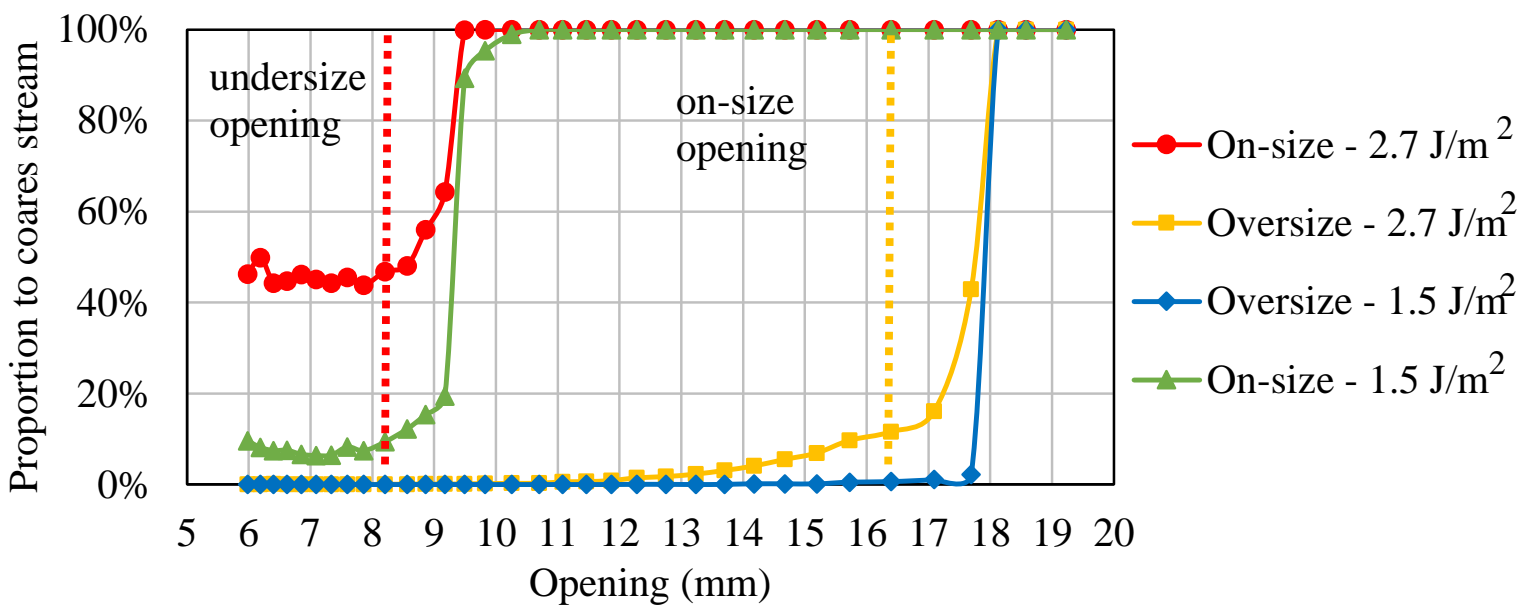

Figure 4. Partition curves results with 2.7 and $1.5 \mathrm{~J} / \mathrm{m}^{2}$, representing a high moisture content simulation, respectively, of surface energy in JKR the contact model.

Table 1. Summarized results for simulations involving different moisture contents represented by the choice of different cohesion energies in the JKR model

\begin{tabular}{lcc}
\hline \multirow{2}{*}{\multicolumn{1}{c}{ Response }} & JKR Surface Energy Pellet-Pellet \\
\cline { 2 - 3 } & $1.5 \mathrm{~J} / \mathrm{m}^{2}$ & $2.7 \mathrm{~J} / \mathrm{m}^{2}$ \\
\hline Production loss in undersize & $85.2 \mathrm{t} / \mathrm{h}$ & $47.1 \mathrm{t} / \mathrm{h}$ \\
Production share in undersize & $67.5 \%$ & $66.1 \%$ \\
Production loss in oversize & $2.1 \mathrm{t} / \mathrm{h}$ & $53.4 \mathrm{t} / \mathrm{h}$ \\
Total production loss & $87.3 \mathrm{t} / \mathrm{h}$ & $100.5 \mathrm{t} / \mathrm{h}$ \\
Production share in oversize & $7.7 \%$ & $57.3 \%$ \\
Discs return rate & $11.0 \%$ & $11.6 \%$ \\
Discs undersize return rate & $9.0 \%$ & $5.0 \%$ \\
Discs oversize return rate & $1.97 \%$ & $6.58 \%$ \\
On-size contamination & $3.5 \mathrm{t} / \mathrm{h}$ & $20.2 \mathrm{t} / \mathrm{h}$ \\
On-size contamination share & $0.28 \%$ & $1.61 \%$ \\
Fines removal efficiency (FRE) & $92.4 \%$ & $54.4 \%$ \\
Product screening efficiency (PSE) & $92.9 \%$ & $91.7 \%$
\end{tabular}




\subsection{Undersize gap}

The present work deals with a range of solids with sizes that vary in a narrow size range. The differences pursued for discs return rates, although may influence some millions of dollars if analyzed on the basis of annual amounts, are reasonably small $(0.5-2.5 \%)$. The actual case analysis is carried out for undersize gap lengths of 7.5 $\mathrm{mm}$ and $9.0 \mathrm{~mm}$. Both openings have already been used in actual operation. All the other input parameter and geometry dimension are maintained constant.

Results are plotted in Figure 5. For a narrower gap, it is evident that the loss of production practically vanishes, since the finer product pellets $(8-10 \mathrm{~mm})$ are unable to pass through the undersize gaps. However, on-size contamination is 3.4 times greater than when the $9.0 \mathrm{~mm}$ gapped screen is used. $20 \%$ of fines by-pass is a substantial amount comparable for example to hydrocyclones separation process. Indeed, this narrower setting is not advisable in practical application due to the high amount of fines contaminating the on-size stream and results are in very good agreement with previous results reported in literature ${ }^{11}$. At the same time, due the narrower gap, the $7.5 \mathrm{~mm}$ gapped screen works with a larger amount of pellets at the on-size screening area. As consequence, the loss of product to oversize is 4.5 times larger. The global screening efficiency (GSE), i.e, the product of fines removal and product screening efficiencies (FRE and PSE, respectively), is almost $7 \%$ smaller for the narrower gap as detailed in Table 2.

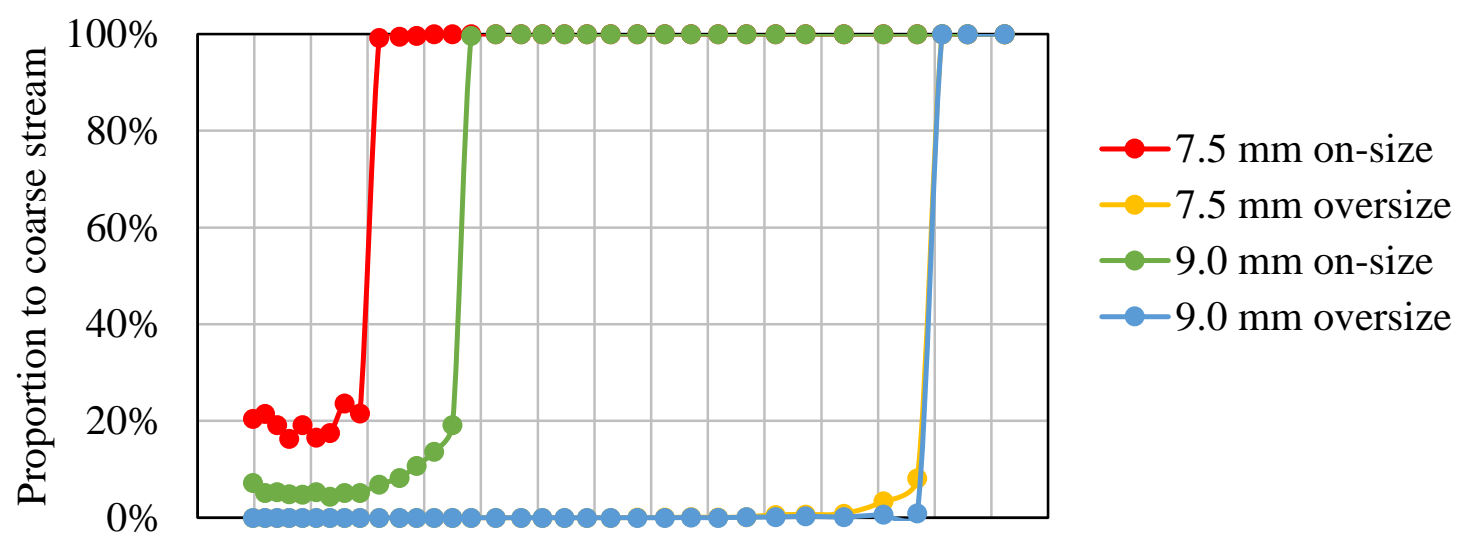

$\begin{array}{llllllllll}5 & 6 & 7 & 8 & 9 & 1011 & 12 & 1314151617181920\end{array}$

Opening $(\mathrm{mm})$

Figure Erro! Nenhum texto com o estilo especificado foi encontrado no documento.. Partition curves results for 7.5 and $9.0 \mathrm{~mm}$ undersize gaps.

Table 2. Summarized results for $7.5 \mathrm{~mm}$ and $9.0 \mathrm{~mm}$ undersize gaps lengths

Response

\begin{tabular}{l}
\multicolumn{1}{c}{ Response } \\
\hline Production loss in undersize \\
Production share in undersize \\
Production loss in oversize \\
Total production loss
\end{tabular}


Production share in oversize

Discs return rate

Discs undersize return rate

Discs oversize return rate

On-size contamination

On-size contamination share

Fines removal efficiency (FRE)

Product screening efficiency (PSE)

Global screening efficiency (GSE)
$10.1 \%$

$5.67 \%$

$2.5 \%$

$3.14 \%$

$8.74 \mathrm{t} / \mathrm{h}$

$0.65 \%$

$80.0 \%$

$99.5 \%$

$79.6 \%$
$2.3 \%$

$13.68 \%$

$10.7 \%$

$2.96 \%$

$2.60 \mathrm{t} / \mathrm{h}$

$0.21 \%$

$94.3 \%$

$91.6 \%$

$86.42 \%$

\subsection{Pellets stiffness}

A theoretical comparison of situations was carried out in order to assess how modelling responses vary to distinct pellets stiffness. The shear modulus input parameter was set $1 \mathrm{MPa}$ and $2.4 \mathrm{MPa}$ for equal simulations, i.e., all other input parameter remained unaltered. Results are presented in Figure 5 and Table 2.

One of the important findings from the model calibration was the significant influence of shear modulus on the simulation outcome. As it can be noticed in Figure 5.4, results of compression tests showed the inherent variance among pellets, even though produced under controlled conditions in laboratory and reflected that mean shear modulus can range in some extent (further details are discussed in dedicated works to green pellets strength ${ }^{12}$ ). When the shear modulus is set to a larger value, i.e., pellets are more rigid, the result is an increase in the amount of oversize to an extent that did not correspond to real situations. In contrast to that, softer particles exhibited larger elastic deformation, i.e., let higher overlaps take place (Figure 7), being pulled through rolls gaps and increase the undersize stream. Fines by-pass is slightly higher for softer particles because production pellets occupy the gap passage hauling fines downstream. For the same reason the smaller production pellets ( 9 to $10 \mathrm{~mm}$ ) share in on-size is lower for the low-level case as they were screened in undersize. Global screening efficiency decreased substantially indicating the highly relevant the role of elastic-plastic deformation for pellets classifying in roller screens.

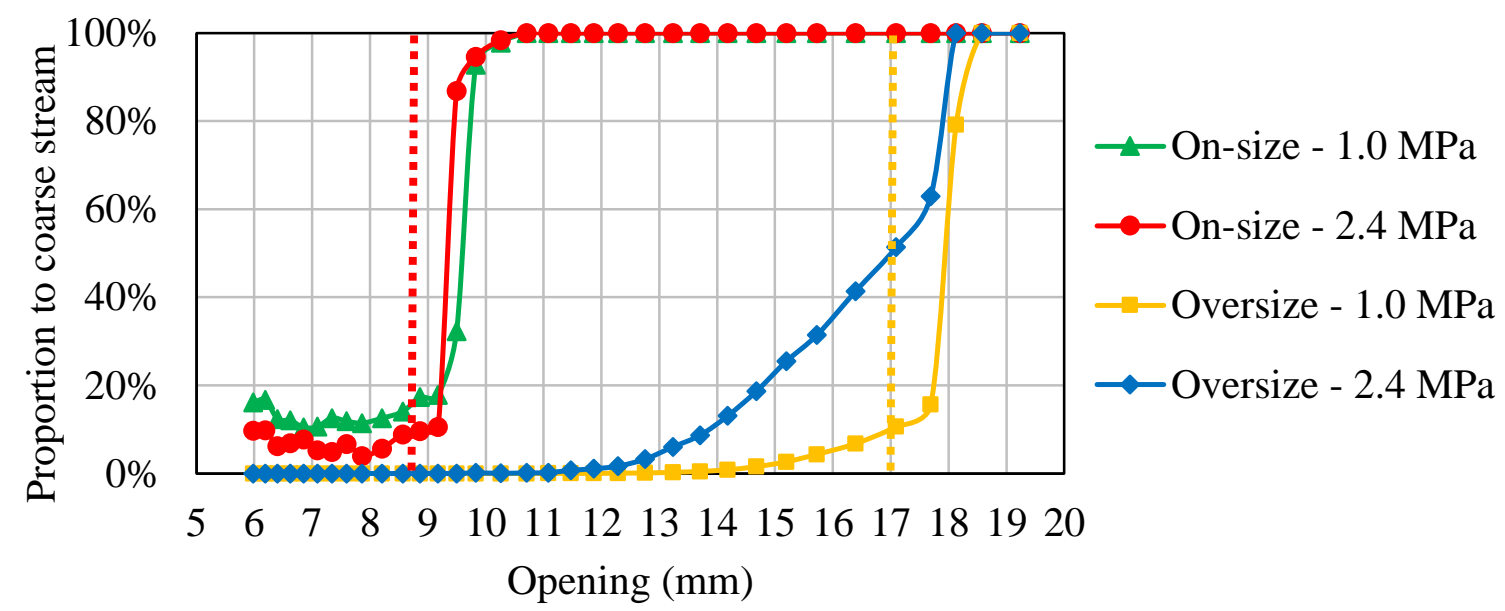

Figure 6. Partition curves results for 1.0 MPa and 2.4 MPa shear modulus pellets.

Table 3. Summarized results for softer and more rigid solids 


\begin{tabular}{lcc}
\hline \multirow{2}{*}{ Response } & \multicolumn{2}{c}{ Shear modulus } \\
\cline { 2 - 3 } & $1.0 \mathrm{MPa}$ & $2.4 \mathrm{MPa}$ \\
\hline Production loss in undersize & $38.6 \mathrm{t} / \mathrm{h}$ & $36.3 \mathrm{t} / \mathrm{h}$ \\
Production share in undersize & $68.7 \%$ & $65.5 \%$ \\
Production loss in oversize & $31.6 \mathrm{t} / \mathrm{h}$ & $219.7 \mathrm{t} / \mathrm{h}$ \\
Total production loss & $70.2 \mathrm{t} / \mathrm{h}$ & $256.0 \mathrm{t} / \mathrm{h}$ \\
Production share in oversize & $23.8 \%$ & $68.0 \%$ \\
Discs return rate & $13.3 \%$ & $26.4 \%$ \\
Discs undersize return rate & $3.9 \%$ & $3.9 \%$ \\
Discs oversize return rate & $9.3 \%$ & $22.5 \%$ \\
On-size contamination & $5.14 \mathrm{t} / \mathrm{h}$ & $1.65 \mathrm{t} / \mathrm{h}$ \\
On-size contamination share & $0.42 \%$ & $0.16 \%$ \\
Fines removal efficiency (FRE) & $86.2 \%$ & $89.9 \%$ \\
Product screening efficiency (PSE) & $94.5 \%$ & $77.7 \%$ \\
Global screening efficiency (GSE) & $81.5 \%$ & $69.9 \%$ \\
\hline
\end{tabular}

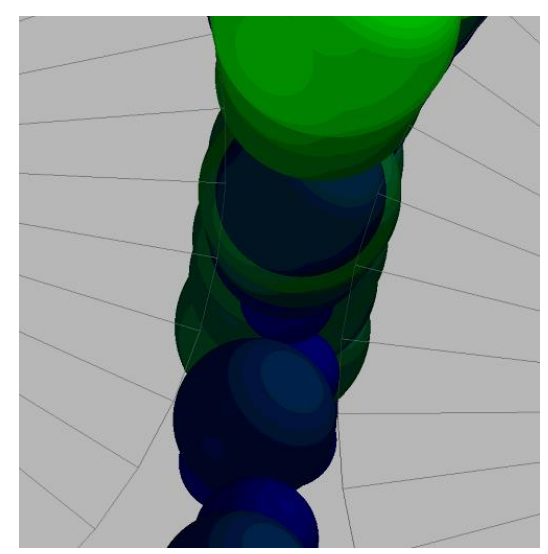

Figure 7. Snapshot of roller screen simulation showing pellets passing through rolls gap. Deformation simulated through overlaps for the case with a shear modulus of $2.4 \mathrm{MPa}$.

\subsection{Feed size distribution sensibility}

Two distinct feed size distributions (fine and coarse) were simulated to evaluate its effect on roller screen performance obtained through simulations (Figure 8). These size distributions are based on the first and third quartiles of pellets mean historical diameter. 


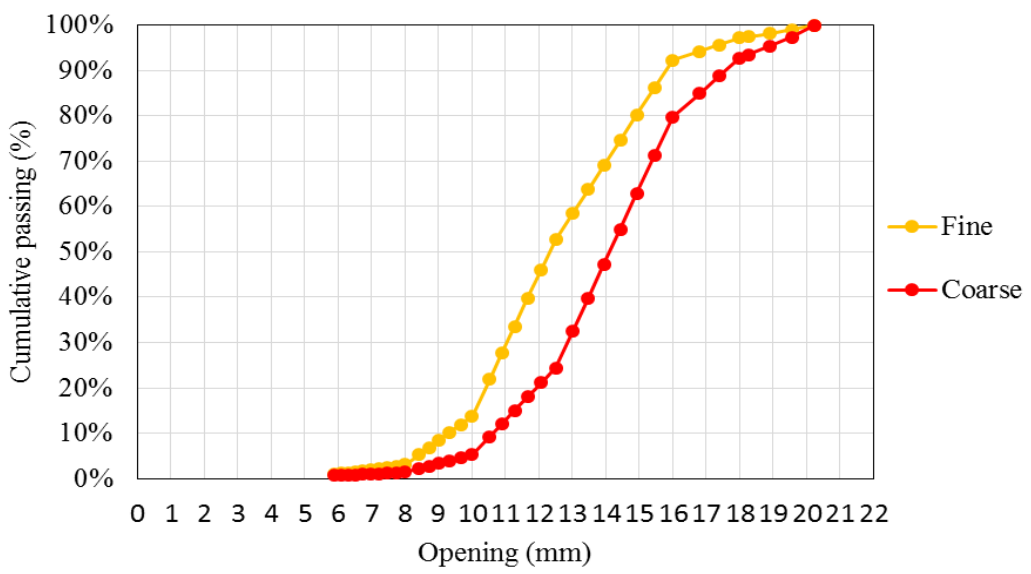

Figure 8. Fine and coarse size distributions.

Results shown in Figure 9 and Table 4 are in agreement with observations in real industrial operations. When discs produce smaller (higher specific surface area, low moisture content, fine feed fineness, higher addition of bentonite etc) or larger pellets for any reason, the response of discs return rate is immediate and balling yield unavoidably decreases. Discs control and maintenance are very relevant to reach success on pellets formation and higher rates balling outputs.

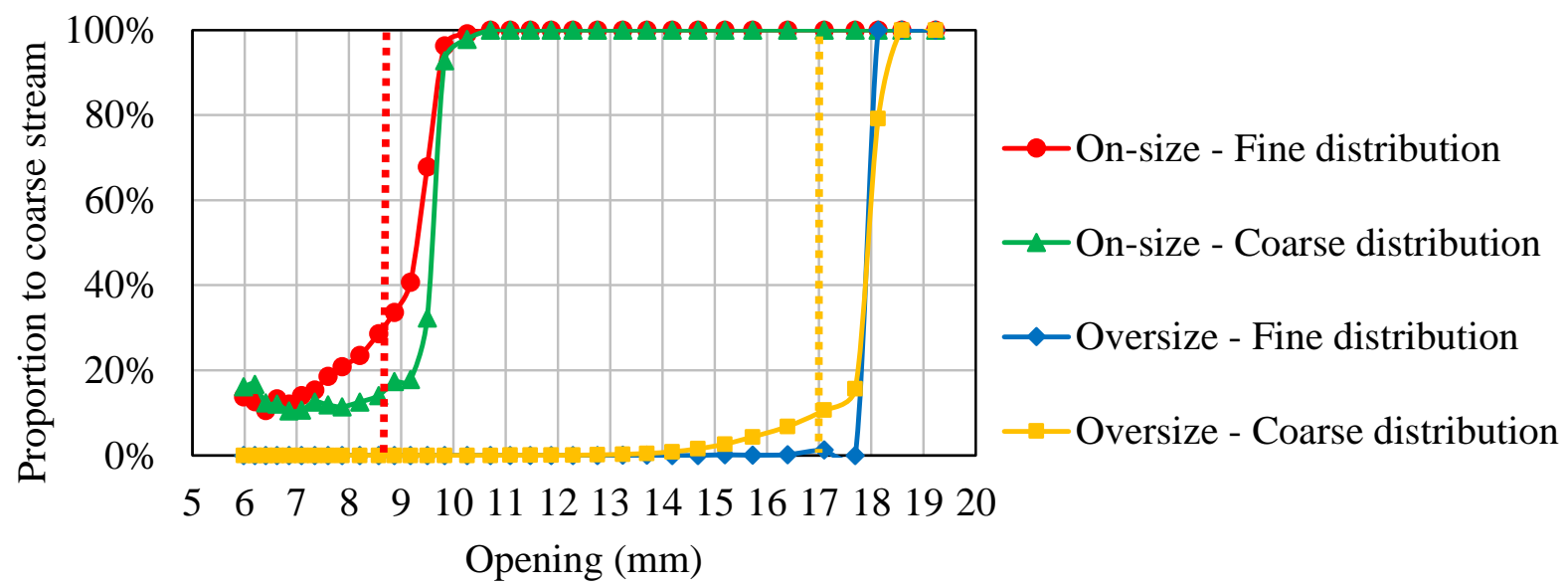

Figure 9. Partition curves results for feeds containing fine and coarse pellet size distributions.

Table 4. Summarized results for softer and more rigid solids

\begin{tabular}{lcc}
\hline \multirow{2}{*}{ Response } & \multicolumn{2}{c}{ Size distribution } \\
\cline { 2 - 3 } & Fine & Coarse \\
\hline Production loss in undersize & $78.9 \mathrm{t} / \mathrm{h}$ & $38.6 \mathrm{t} / \mathrm{h}$ \\
Production share in undersize & $67.7 \%$ & $68.7 \%$ \\
Production loss in oversize & $0.6 \mathrm{t} / \mathrm{h}$ & $31.6 \mathrm{t} / \mathrm{h}$ \\
Total production loss & $79.5 \mathrm{t} / \mathrm{h}$ & $70.2 \mathrm{t} / \mathrm{h}$ \\
Production share in oversize & $1.3 \%$ & $23.8 \%$ \\
Discs return rate & $11.2 \%$ & $13.3 \%$ \\
Discs undersize return rate & $8.2 \%$ & $3.9 \%$ \\
Discs oversize return rate & $2.95 \%$ & $9.33 \%$
\end{tabular}


On-size contamination

On-size contamination share

Fines removal efficiency (FRE)

Product screening efficiency (PSE)

Global screening efficiency (GSE)
$6.44 \mathrm{t} / \mathrm{h}$

$0.51 \%$

$84.4 \%$

$93.6 \%$

$79.1 \%$
$5.14 \mathrm{t} / \mathrm{h}$

$0.42 \%$

$86.2 \%$

$94.5 \%$

$81.5 \%$

\section{CONCLUSIONS}

Exploratory simulations have reproduced, both qualitatively and quantitatively, the effects of important process variables on the classification of green pellets on roller screens, namely moisture content, undersize gap length, size distribution and pellets resistance, that are observed in reality. DEM approach demonstrated to be a powerful tool which may overcome the limitations imposed of a complex balling industrial process and guide modifications in it to improve results with more certainty.

\section{Acknowledgements}

The authors would like to thank Vale for the funding of the research and to support one of the authors (B.B. Silva) in conducting his master's studies. The other authors are grateful to the sponsoring agencies CNPq, CAPES and FAPERJ for their support through the scholarships granted.

\section{REFERENCES}

1 WANG, D; SERVIN, M; BERGLUND, T; MICKELSSON, K.-O; RÖNNBÄCK, S.

Parametrization and Validation of a Nonsmooth Discrete Element Method for Simulating Flows of Iron Ore Green Pellets. Powder Technology, 283, pp. 475-487, 2015.

SASTRY, K.V.S. How to Produce Designer Pellets of Our Choice Through a Process

Engineering Approach. 2nd COREM Symposium on Iron Ore Pelletizing, Quebec City,

Canada, 2008.

3 OptProcess Manual, 2009.

4 CLEARY, P.W. Recent Advances in DEM Modelling of Tumbling Mills. Minerals Engineering, 14, pp. 1295-1319, 2001.

5 CLEARY, P.W; METCALFE, G; LIFFMAN, K. How Well Do Discrete Element Granular Flow Models Capture the Essentials of Mixing Process? Applied Mathematical Modelling, 22, pp. 995-1008, 1998.

6 CLEARY, P.W. DEM Simulation of Industrial Particle Flows: Case Studies of Dragline Excavators, Mixing in Tumblers and Centrifugal Mills. Powder Technology, 109, pp. 83104, 2000.

7 WEERASEKARA, N.S; POWELL, M.S; CLEARY, P.W; TAVARES, L.M; EVERTSSON,M; MORRISON, R.D; QUIST, J. CARVALHO, R.M. The contribution of DEM to the science of comminution. Powder Technology, 248, pp. 3-24, 2013. 2012];11:74-92. Disponível em: http://www.cgee.org.br/arquivos/pe_11.pdf.

8 LIAN, G; THORNTON, C; ADAMS, M.J. A Theoretical Study of the Liquid Bridge Forces between Two Rigid Spherical Bodies. Journal of Colloid and Interface Science, 161, pp. 138-147, 1993.

9 MISHRA, B.K; THORNTON, C; BHIMJI, D. A Preliminary Numerical Investigation of Agglomeration in a Rotary Drum. Minerals Engineering, 15, pp. 27-33, 2002.

10 SILVA, B.B. Modelling and Optimization of Green Pellets Classification on Roller Screens Using The Discrete Element Method. Tese de Dissertação.

COPPE/Universidade Federal do Rio de Janeiro, Rio de Janeiro, 2007 
11 WELLSTEAD, P.E; CROSS, M; MUNRO, N; IBRAHIM, D. On the Design and Assessment of Control Schemes for Balling-Drum Circuits Used in Pelletising. International Journal of Mineral Processing, 5, pp. 45-67, 1978.

12 FORSMO, S.P.E; APELQVIST, A.J; BJÖRKMAN, B.M.T; SAMSKOG, P.-O. Binding Mechanisms in Wet Iron Ore Green Pellets with Bentonite Binder. Powder Technology, 169, pp. 147-158, 2006. 